\title{
VITAMIN C SATURATION LEVELS IN THE BODY IN NORMAL SUBJECTS AND IN VARIOUS PATHOLOGICAL CONDITIONS ${ }^{1}$
}

\author{
By PHILIP FINKLE \\ (From the Division of Laboratories and from the Medical Service of Dr. George Baehr, \\ the Mt. Sinai Hospital, New York City)
}

(Received for publication January 29, 1937)

There is still doubt concerning the rôle which vitamin $\mathrm{C}$ deficiency plays in pathological conditions, other than scurvy, which are characterized by vascular damage and a tendency to hemorrhage.

In a previous communication (2) the writer presented a preliminary report of studies upon urinary excretion of vitamin $\mathrm{C}$ in some vascular diseases, as well as in normal individuals. The rate of excretion in normal cases was found to be between 0.03 and $0.05 \mathrm{mgm}$. per cc. of urine during the day period (less during the night)-approximately that previously reported by Harris, Ray and Ward (1).

The present paper is concerned with further studies upon the utilization and excretion of vitamin $C$ in conditions associated with vascular damage, hemorrhagic tendencies, as well as in other pathological states. One hundred and twentyseven patients and normal controls were studied.

It seemed of interest to ascertain whether there is any change in the level of excretion in the normal individual when a quantity of vitamin $C$ in excess of the usual average daily intake is administered. In order to eliminate the factor of variability in absorption or in destruction in the gastro-intestinal tract, the vitamin $\mathrm{C}$ was administered intravenously. This method was used in the work previously reported by the author (2).

\section{METHOD}

In the earlier experiments presently reported the total 24 hour urinary excretion of vitamin C was first ascertained in each subject. On the following day, usually about 10 a.m., $100 \mathrm{mgm}$. of vitamin C (Merck) dissolved in $5 \mathrm{cc}$. of distilled water was injected intravenously, and again the 24 hour output of vitamin $\mathrm{C}$ in the urine was measured.

1 Aided by a grant from Nelson I. Asiel. Aided, also, by a grant donated in memory of Solomon Sassoon Benjamin.
The results of these studies (Table I) indicate, 1 , that the 24 hour output of vitamin $C$ is usually about 13 to $20 \mathrm{mgm}$., and that the average is between 0.03 and $0.05 \mathrm{mgm}$. per cc. of urine during

TABLE I

Influence of vitamin $C$ injection on vitamin $C$ output

\begin{tabular}{|c|c|c|c|c|}
\hline \multirow[b]{2}{*}{ Initials and remarks } & \multicolumn{2}{|c|}{$\begin{array}{l}\text { Without } \\
\text { intravenous } \\
\text { vitamin C }\end{array}$} & \multicolumn{2}{|c|}{$\begin{array}{l}\text { On day of } \\
\text { vitamin C } \\
\text { injection }\end{array}$} \\
\hline & $\begin{array}{l}\text { Total } \\
24 \\
\text { hour } \\
\text { out- } \\
\text { put }\end{array}$ & $\begin{array}{l}\text { Average } \\
\text { output } \\
\text { per } \\
\text { day- } \\
\text { time } \\
\text { voiding }\end{array}$ & $\begin{array}{l}\text { Output } \\
\text { in } 2 \text { to } \\
3 \text { hours } \\
\text { after } \\
\text { injec- } \\
\text { tion }\end{array}$ & $\begin{array}{l}\text { Total } \\
24 \\
\text { hour } \\
\text { out- } \\
\text { put }\end{array}$ \\
\hline - & mgm. & mgm. & mgm. & $m g m$. \\
\hline \multicolumn{5}{|c|}{ NORMAL INDIVIDUALS } \\
\hline 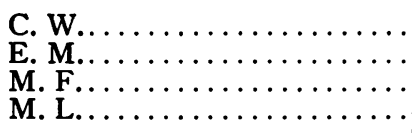 & $\begin{array}{l}16.0 \\
21.0 \\
13.4 \\
21.0\end{array}$ & $\begin{array}{l}3.8 \\
4.5 \\
4.0 \\
5.3\end{array}$ & $\begin{array}{l}25.7 \\
25.0 \\
40.0 \\
26.0\end{array}$ & $\begin{array}{l}45.0 \\
64.0 \\
63.0 \\
60.0\end{array}$ \\
\hline \multicolumn{5}{|c|}{ ABNORMAL INDIVIDUALS } \\
\hline $\begin{array}{l}\text { J. H. Bleeding peptic ulcer.... } \\
\text { A. W. Gonorrheal arthritis .... } \\
\text { D. T. Luetic aortitis. ........ } \\
\text { S. S. Carcinoma of bronchus.. }\end{array}$ & $\begin{array}{l}7.7 \cdot \\
9.0 \\
9.0 \\
9.1\end{array}$ & $\begin{array}{l}1.0 \\
1.6 \\
1.5 \\
1.1\end{array}$ & $\begin{array}{l}1.0 \\
2.5 \\
1.5 \\
2.1\end{array}$ & $\begin{array}{r}8.0 \\
13.0 \\
9.0 \\
9.3\end{array}$ \\
\hline
\end{tabular}

the day period (being less during the night period). 2 , In from 2 to 3 hours following the intravenous administration of $100 \mathrm{mgm}$. vitamin $C$, the excretion per cubic centimeter of urine rises to about 6 times the pre-injection level. The total 24 hour output rises to 45 to $65 \mathrm{mgm}$. vitamin $C$. This means that in addition to the usual daily output, 30 to 50 per cent (or more) of the vitamin $C$ injected is excreted in the urine within the first 24 hours. 3, In those cases in which the output of vitamin $\mathrm{C}$ in individual voidings falls much below $3.0 \mathrm{mgm}$. the total output for the 24 hour period is considerably below the normal lev- 
els. 4, When there is no acute rise in excretion following the intravenous administration of vitamin C, the total output for the 24 hour period remains at about the same low level as on the previous day, when no vitamin $\mathrm{C}$ was injected.

It was therefore considered unnecessary to continue to measure the total excretion of vitamin C for the entire 24 hour period. For the purposes of the investigation described here, the measurement of the total urinary excretion of vitamin C for about an 8 hour period during the day, including an approximately 6 hour period following intravenous injection, suffices to give a true indication of the state of saturation of the body with vitamin $\mathrm{C}$.

To determine the state of body saturation with vitamin $\mathrm{C}$ the following routine was adopted by the present writer. On the day of the test the subject is permitted to have his or her usual meals, with the exception of citrus fruits and other foods containing vitamin $\mathrm{C}$. There is no restriction of fluids. The urine is collected at about 9 a.m. and 11 a.m., and the vitamin $C$ content determined in each specimen. After the 11 a.m. voiding, $100 \mathrm{mgm}$. vitamin $\mathrm{C}$ (cevitamic acid, or cebione, Merck) ${ }^{2}$ dissolved in 5 cc. of distilled water was administered intravenously. The subject then was requested to void only at about $1: 30$, $3: 30$, and $5: 30$ p.m. respectively, and the vitamin $\mathrm{C}$ content was again determined. For the titration of cevitamic acid, 2:6-dichlorophenolindophenol as used by Harris, Ray and Ward (1) was employed. No untoward symptoms were noted, although more than 200 intravenous injections were given.

Since it was the purpose of this work to study subjects under normal conditions, no dietary restrictions were placed upon them other than those stated above.

The normal controls were chosen from among nurses, hospital internes, and laboratory technicians.

It is seen from Table II that in each of the 9 normal controls, following the intravenous administration of $100 \mathrm{mgm}$. of vitamin $\mathrm{C}$, the excretion rises to about 4 to 8 times the values found before the injections.

2 The author wishes to express his appreciation to Merck and Co. for their generous cooperation in supplying us with the ascorbic acid required in these studies.
TABLE II

Influence of vitamin $C$ injection on vitamin $C$ output

\begin{tabular}{c|c|c|c}
\hline \hline Name & $\begin{array}{c}\text { Before } \\
\text { injection }\end{array}$ & \multicolumn{2}{|c}{ After injection } \\
\cline { 2 - 4 } & $\begin{array}{c}6: 30 \text { to } \\
11 \text { a.m. }\end{array}$ & 11 a.m. to & $1: 30$ to \\
& & $1: 30$ p.m. & $5: 30$ p.m. \\
\hline & mom. & mom. & mom. \\
\hline
\end{tabular}

NORMAL CONTROLS

\begin{tabular}{|c|c|c|c|}
\hline 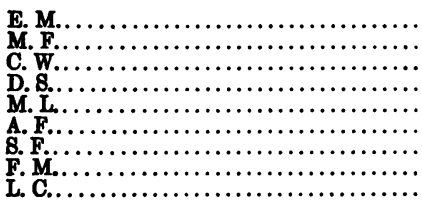 & $\begin{array}{l}3.9 \\
6.0 \\
3.8 \\
5.6 \\
5.3 \\
7.1 \\
3.2 \\
4.4 \\
5.1\end{array}$ & $\begin{array}{l}25.0 \\
40 . \\
25.7 \\
17.0 \\
26.0 \\
31.0 \\
24.0 \\
16.3 \\
19.2\end{array}$ & $\begin{array}{r}10.0 \\
7.0 \\
4.3 \\
7.0 \\
5.0 \\
9.2 \\
6.0 \\
6.0 \\
4.8\end{array}$ \\
\hline
\end{tabular}

PURPORAS

\begin{tabular}{|c|c|c|c|c|}
\hline $\begin{array}{l}\text { Y. K. } \\
\text { R.LaC. } \\
\text { T. G. } \\
\text { A. N. } \\
\text { I. E. } \\
\text { D. D. } \\
\text { A. K. } \\
\text { G. S. } \\
\text { F. B. } \\
\text { E. G. } \\
\text { M. M. } \\
\text { T. Gr. } \\
\text { M. K. } \\
\text { B. B. } \\
\text { R. F. } \\
\text { A. A. } \\
\text { A. R. } \\
\text { F. G. } \\
\text { A. E. }\end{array}$ & 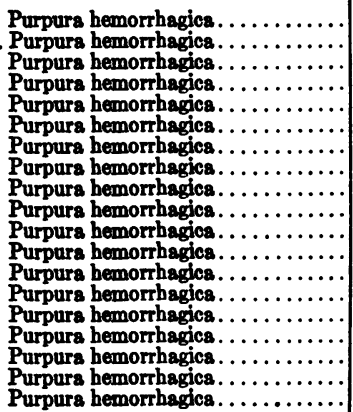 & $\begin{array}{l}2.1 \\
2.6 \\
5.0 \\
2.4 \\
3.5 \\
6.0 \\
3.0 \\
2.0 \\
1.8 \\
1.0 \\
1.8 \\
2.7 \\
1.9 \\
6.5 \\
2.9 \\
1.7 \\
2.0 \\
1.9 \\
2.7\end{array}$ & $\begin{array}{r}3.2 \\
4.5 \\
32.0 \\
8.3 \\
4.1 \\
19.0 \\
5.0 \\
2.1 \\
1.4 \\
2.6 \\
2.1 \\
3.8 \\
4.2 \\
33.0 \\
4.1 \\
8.1 \\
1.8 \\
2.0 \\
3.1\end{array}$ & $\begin{array}{l}1.3 \\
3.0 \\
6.1 \\
2.0 \\
2.1 \\
4.1 \\
3.0 \\
1.7 \\
1.0 \\
1.8 \\
2.0 \\
1.1 \\
3.4 \\
4.1 \\
3.0 \\
2.4 \\
1.9 \\
2.4 \\
2.1\end{array}$ \\
\hline $\begin{array}{l}\text { R. B. } \\
\text { R. C. } \\
\text { R. G. }\end{array}$ & $\begin{array}{l}\text { Symptomatic purpura } \ldots \ldots \ldots \ldots \cdots \cdots \\
\text { Symptomatic purpura } \ldots \ldots \ldots \ldots \cdots \cdots \\
\text { Symptomatic purpura } \ldots \ldots \ldots \ldots \cdots \cdots\end{array}$ & $\begin{array}{l}1.4 \\
1.5 \\
1.2\end{array}$ & $\begin{array}{l}3.0 \\
3.8 \\
1.5\end{array}$ & $\begin{array}{l}1.0 \\
2.0 \\
0.9\end{array}$ \\
\hline $\begin{array}{l}\text { V. } \mathbf{B} . \\
\text { J. } \\
\mathbf{M} . \dot{\mathbf{K}}\end{array}$ & 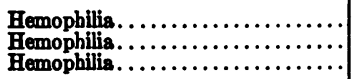 & $\begin{array}{l}3.6 \\
7.1 \\
3.9\end{array}$ & $\begin{array}{r}5.3 \\
23.0 \\
38.2\end{array}$ & $\begin{array}{l}3.3 \\
8.0 \\
5.3\end{array}$ \\
\hline $\begin{array}{l}\text { E. Z. } \\
\text { M.t. } \\
\text { F. B. } \\
\text { R. B. }\end{array}$ & 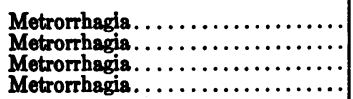 & $\begin{array}{l}3.5 \\
2.7 \\
2.1 \\
1.9\end{array}$ & $\begin{array}{l}6.2 \\
1.7 \\
3.2 \\
2.1\end{array}$ & $\begin{array}{l}1.7 \\
1.4 \\
1.8 \\
1.1\end{array}$ \\
\hline
\end{tabular}

ACU2W LUPUS ERTTHEMATOSUS

\begin{tabular}{|c|c|c|c|}
\hline 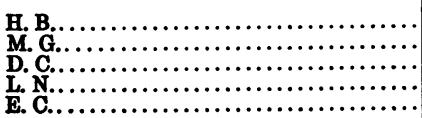 & $\begin{array}{l}1.0 \\
2.2 \\
1.1 \\
1.8 \\
2.0\end{array}$ & $\begin{array}{l}2.1 \\
6.1 \\
2.0 \\
1.1 \\
2.1\end{array}$ & $\begin{array}{l}1.5 \\
3.0 \\
0.8 \\
1.0 \\
1.8\end{array}$ \\
\hline
\end{tabular}

NEPBRITIS

\begin{tabular}{|c|c|c|c|}
\hline $\begin{array}{l}\text { M. U. Acute glomerular nephritis.......... } \\
\text { P. R. Acute glomerular nephritis } \ldots \ldots \ldots \ldots \ldots \\
\text { E. C. Acute glomerular nephritis } \ldots \ldots \ldots \ldots \ldots \\
\text { A. D. Acute glomerular nephritis............. }\end{array}$ & $\begin{array}{l}1.4 \\
3.1 \\
1.0 \\
0.9\end{array}$ & $\begin{array}{r}12.2 \\
11.1 \\
1.6 \\
2.6\end{array}$ & $\begin{array}{l}2.0 \\
1.3 \\
1.5 \\
1.1\end{array}$ \\
\hline 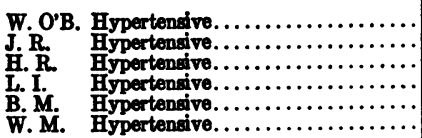 & $\begin{array}{l}3.2 \\
\mathbf{3 . 0} \\
2.0 \\
2.3 \\
1.5 \\
1.3\end{array}$ & $\begin{array}{r}9.4 \\
20.5 \\
8.6 \\
3.9 \\
2.6 \\
1.4\end{array}$ & $\begin{array}{l}2.1 \\
6.8 \\
1.1 \\
3.6 \\
1.2 \\
1.9\end{array}$ \\
\hline
\end{tabular}


TABLE II-Continued

\begin{tabular}{|c|c|c|c|}
\hline \multirow{2}{*}{ Name } & \multirow{2}{*}{$\begin{array}{c}\text { Before } \\
\text { injection } \\
6: 30 \text { to } \\
11 \mathrm{am} .\end{array}$} & \multicolumn{2}{|c|}{ After injection } \\
\hline & & $\begin{array}{l}11 \text { a.m. to } \\
1: 30 \text { p.m. }\end{array}$ & $\begin{array}{c}\text { 1:30 to } \\
\text { 5:30 p.m. }\end{array}$ \\
\hline & mom. & mom. & mom. \\
\hline \multicolumn{4}{|c|}{ ACUTE RHEOMATC WVR } \\
\hline 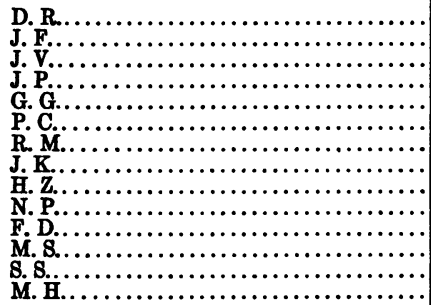 & $\begin{array}{l}1.0 \\
1.9 \\
2.1 \\
2.0 \\
3.2 \\
2.0 \\
1.1 \\
2.7 \\
1.7 \\
2.0 \\
2.8 \\
2.5 \\
4.4 \\
4.7\end{array}$ & \begin{tabular}{r|}
1.1 \\
2.3 \\
9.1 \\
4.1 \\
8.4 \\
9.1 \\
2.3 \\
5.3 \\
6.1 \\
1.9 \\
19.1 \\
3.1 \\
20.2 \\
19.8
\end{tabular} & $\begin{array}{l}1.6 \\
1.2 \\
2.0 \\
2.2 \\
5.0 \\
1.8 \\
1.0 \\
3.1 \\
2.9 \\
1.1 \\
2.0 \\
1.9 \\
3.8 \\
3.2\end{array}$ \\
\hline
\end{tabular}

\begin{tabular}{|c|c|c|c|}
\hline \multicolumn{4}{|c|}{ RHEUMATOID ARTBRITIS } \\
\hline 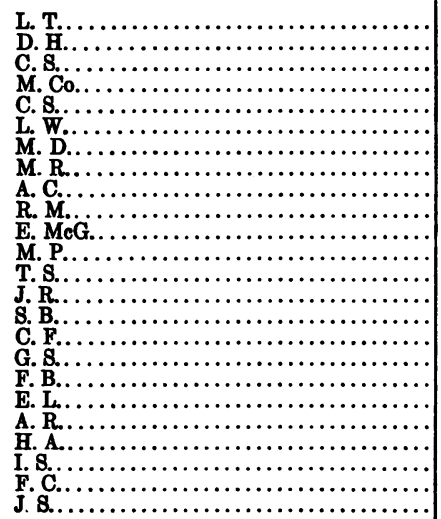 & $\begin{array}{l}2.1 \\
0.9 \\
2.8 \\
3.1 \\
0.9 \\
7.1 \\
1.8 \\
3.4 \\
1.4 \\
1.4 \\
1.1 \\
2.0 \\
5.1 \\
1.9 \\
2.3 \\
1.8 \\
1.4 \\
1.9 \\
1.0 \\
2.0 \\
1.7 \\
0.8 \\
1.4 \\
2.0\end{array}$ & $\begin{array}{r}3.0 \\
2.0 \\
11.3 \\
13.4 \\
1.1 \\
23.0 \\
2.1 \\
4.1 \\
1.9 \\
1.9 \\
2.3 \\
2.1 \\
18.4 \\
2.1 \\
1.4 \\
1.1 \\
2.0 \\
7.1 \\
1.2 \\
2.1 \\
2.0 \\
0.9 \\
1.1 \\
2.1\end{array}$ & $\begin{array}{l}1.8 \\
1.1 \\
1.9 \\
2.0 \\
1.0 \\
4.4 \\
2.1 \\
1.8 \\
0.9 \\
1.4 \\
1.3 \\
1.4 \\
1.8 \\
1.6 \\
0.8 \\
2.2 \\
1.1 \\
1.9 \\
0.6 \\
0.9 \\
1.8\end{array}$ \\
\hline
\end{tabular}

\begin{tabular}{|c|c|c|c|c|}
\hline \multicolumn{5}{|c|}{ JAUNDICI } \\
\hline $\begin{array}{l}\text { M. S. } \\
\text { J. F. } \\
\text { M. C. } \\
\text { I. A. } \\
\text { T. R. } \\
\text { S.G. } \\
\text { H. S. } \\
\text { M.Cr. } \\
\text { F. S. } \\
\text { E. H. } \\
\text { H.Sa. } \\
\text { J. S. } \\
\text { L. } 0 .\end{array}$ & 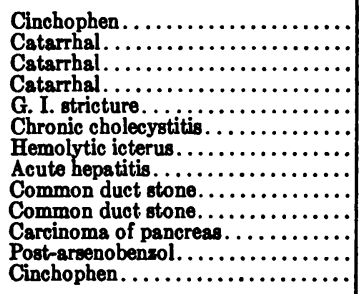 & $\begin{array}{l}6.1 \\
3.9 \\
5.6 \\
1.8 \\
2.0 \\
1.1 \\
0.9 \\
6.3 \\
1.9 \\
2.4 \\
6.1 \\
1.1 \\
7.2\end{array}$ & $\begin{array}{r}37.0 \\
8.4 \\
31.4 \\
3.2 \\
2.1 \\
1.3 \\
2.3 \\
31.2 \\
2.9 \\
3.1 \\
39.0 \\
29.6 \\
49.1\end{array}$ & $\begin{array}{l}5.8 \\
4.4 \\
6.1 \\
1.1 \\
1.8 \\
1.0 \\
1.7 \\
5.8 \\
2.0 \\
1.8 \\
5.0 \\
1.4\end{array}$ \\
\hline \multicolumn{5}{|c|}{ MTBCELLANEOUB GROUP } \\
\hline $\begin{array}{l}\text { L. D. } \\
\text { L. L. } \\
\text { W. G. } \\
\text { W. K. } \\
\text { G. G. } \\
\text { I. H. }\end{array}$ & 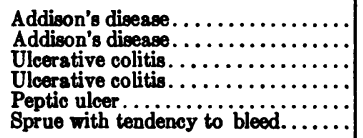 & $\begin{array}{l}1.1 \\
5.5 \\
1.7 \\
1.7 \\
1.3 \\
1.3\end{array}$ & $\begin{array}{r}2.4 \\
21.4 \\
2.3 \\
2.4 \\
2.4 \\
2.8\end{array}$ & $\begin{array}{l}1.3 \\
4.7 \\
1.2 \\
1.1 \\
1.3 \\
1.5\end{array}$ \\
\hline
\end{tabular}

CLINIC CONTROLS

\begin{tabular}{|c|c|c|c|c|}
\hline $\begin{array}{l}\text { M.T. } \\
\text { A.S. } \\
\text { L. H. } \\
\text { M.C. } \\
\text { J.G. } \\
\text { E. T. }\end{array}$ & 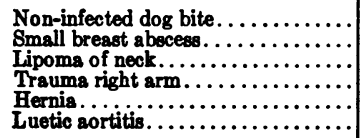 & $\begin{array}{l}1.2 \\
2.5 \\
0.8 \\
1.4 \\
1.9 \\
1.3\end{array}$ & $\begin{array}{l}2.2 \\
2.3 \\
1.5 \\
1.8 \\
3.9 \\
3.0\end{array}$ & $\begin{array}{l}1.1 \\
0.9 \\
1.0 \\
1.1 \\
2.0 \\
1.7\end{array}$ \\
\hline
\end{tabular}

The pre-injection values for vitamin C excretion given in the first column in Table II are the averages of the values for the two voidings prior to the intravenous injection.

From an average excretion of about 4.0 to 7.0 mgm. of vitamin $C$ prior to intravenous injection, the excretion rises, within 2 to 3 hours after injection, to levels of from 16.0 to $40.0 \mathrm{mgm}$. of vitamin $\mathrm{C}$. The normal level is again reached in about 4 to 6 hours.

\section{The purpuras}

The knowledge that scurvy was associated with a dietary deficiency which may be corrected by the administration of lemons or limes antedates our knowledge of vitamins.

The isolation and synthesis of vitamin $\mathrm{C}$ stimulated a renewed interest in other conditions which, like scurvy, are associated with vascular damage and tendency to hemorrhage. The possibility suggested itself to Szent-Györgyi (5) and others that the purpuras might be associated etiologically with a vitamin C deficiency. Some observers have even used vitamin $\mathrm{C}$ as a therapeutic agent in purpura, and have reported good results.

Studies upon 29 cases of this type are recorded here. Included in this group are 19 cases of thrombocytopenic purpura, 3 cases of symptomatic purpura, and 3 cases of hemophilia. In addition, 4 cases of metrorrhagia in which no organic lesion could be demonstrated were studied with this group.

In comparing the values for vitamin $\mathrm{C}$ excretion in normal persons, with those found in the group of purpuras studied, a significant difference is found, Table II. With few exceptions the excretion is considerably lower in the purpuras than in normal individuals, being as low as $\mathbf{3 0}$ per cent of normal.

Following intravenous administration of cevitamic acid, only 3 of the 19 cases of purpura showed a normal rise in urinary excretion of vitamin C. The values for excretion still remained considerably below the normal levels in the remaining 16 cases.

It is noted that 2 of the 3 cases of hemophilia showed the normal rise in excretion following intravenous administration of vitamin $\mathrm{C}$.

None of the cases of metrorrhagia showed any 
significant rise in excretion of vitamin $C$ following intravenous administration of cevitamic acid.

\section{Acute lupus erythematosus}

Because of the tendency to petechial and purpuric hemorrhages, as well as the characteristic pathological changes found in the smaller blood vessels described by Baehr, Klemperer and Schifrin (3) in cases of acute lupus erythematosus, it seemed possible that this group might in some manner be associated with disturbances in vitamin $\mathrm{C}$ metabolism.

Studies upon 5 cases of acute lupus erythematosus are here presented. All of these cases went to a fatal termination.

As seen from Table II, the average values for excretion of vitamin $C$ in these cases was found to be between 1.0 and $2.0 \mathrm{mgm}$. vitamin $\mathrm{C}$ in each voiding, approximately 30 per cent of the values found in normal individuals. Following the intravenous administration of $100 \mathrm{mgm}$. of vitamin C there was no rise in the urinary output of vitamin C. The values still remained considerably below levels found in normal individuals before intravenous administration of cevitamic acid.

\section{Glomerulonephritis and hypertension}

In the cases of purpura and more particularly in the cases of acute lupus erythematosus there occurs not infrequently a considerable degree of vascular damage in the kidneys. The question arises whether the low excretion of vitamin $\mathrm{C}$ in these cases could be ascribed to diminished excretory activity of the damaged kidneys. Accordingly, a group of 10 cases of acute glomerulonephritis and hypertension with renal vascular involvement was studied. The results of these studies (Table II) indicate that even such severe damage to the capillaries of 'the kidneys as is found in cases of acute glomerulonephritis is not necessarily associated with any decreased permeability of the kidneys for vitamin C. In 5 of the 10 cases studied there is a rise in excretion of vitamin $\mathrm{C}$ following intravenous administration. In one of these 5 cases the rise is to $20.5 \mathrm{mgm}$. of vitamin C. In the other 4 cases the post-injection levels range from 8.6 to $12.2 \mathrm{mgm}$.

\section{Rheumatic fever}

Rinehart et al. (4) suggested that a vitamin C deficiency might be one of the etiological factors in the development of acute rheumatic fever. It was therefore considered of interest to study the vitamin $\mathrm{C}$ excretion in a group of cases of acute rheumatic fever. In Table II there are presented the results of these studies upon 14 cases ranging in age from 12 to 49 years, and in varying stages of the disease. In 6 of the cases there is an increase in excretion of vitamin $\mathrm{C}$ following intravenous injection of $100 \mathrm{mgm}$. of ascorbic acid. While in some of these cases urinary excretion of vitamin $C$ before intravenous injection is below normal, yet, following injection, there are increases in output ranging up to about 7 times the pre-injection level.

\section{Rheumatoid arthritis}

In order to ascertain whether there is any significant difference in vitamin $\mathrm{C}$ metabolism between the cases of acute rheumatic fever and rheumatoid arthritis, 24 cases of the latter group were studied. From Table II it is seen that of the 24 cases studied, only 4 showed a normal vitamin $\mathrm{C}$ excretion curve in the urine. The remaining 20 cases either had excretion levels considerably below normal, or had no rise in excretion following intravenous administration of vitamin C.

\section{Jaundice}

At present there is no satisfactory explanation for the enhanced tendency to bleed in cases of jaundice. The possibility suggests itself that in association with the greater or lesser degree of damage to the liver some disturbance in vitamin C metabolism might be concerned with the increased bleeding tendency. Studies of vitamin C excretion were therefore made upon a group of 13 cases of jaundice of various types. The results of these studies are given in Table II. In 5 of the cases, the vitamin $C$ excretion test is apparently normal, while in the remaining 8 cases there is little or no rise in excretion following the intravenous injection. No uniform disturbance of vitamin $\mathrm{C}$ metabolism was demonstrable in these cases of jaundice.

In Table II are given the results of studies upon a miscellaneous group of 6 cases: 2 cases 
of Addison's disease, 2 cases of ulcerative colitis, 1 case of peptic ulcer, and 1 case of non-tropical sprue. The vitamin $C$ excretion tests in all but one case show a low vitamin $\mathrm{C}$ saturation. The exception is one of the cases of Addison's disease which has a normal excretion curve. A vitamin $C$ deficiency could have been anticipated in the intestinal cases (including the case of sprue) as a result of the dietary restrictions imposed in these cases.

From the foregoing studies upon 115 subjects it is clear that abnormally low vitamin $\mathrm{C}$ excretion levels occur in a variety of pathological conditions. It should be evident, however, that the mere demonstration of an abnormally low vitamin $\mathrm{C}$ excretion level in a given disease is not adequate evidence that the disease is due to a vitamin C deficiency.

The high incidence of low vitamin C saturation in many of the patients studied leads one to suspect that a large percentage of the population from which these clinic and ward patients are drawn is on a low vitamin $C$ intake as a part of a general dietetic deficiency. It was therefore considered desirable to study a group of patients from departments such as the orthopedic clinics and the surgical clinics, in order to ascertain whether they show any vitamin $\mathrm{C}$ deficiency as indicated by a low excretion level.

Six patients were selected at random from the traumatic surgical clinic. These patients were chosen from a group which had no demonstrable vascular disease or tendency to hemorrhage, the conditions being fractures, other trauma, dog bite, etc. From Table II it can be seen that all of these patients have low excretion levels of vitamin $\mathrm{C}$ in the urine, with practically no rise following intravenous injection. These patients had a low vitamin $C$ saturation level, although they had no clinical manifestations which could in any way be associated with a vitamin $\mathrm{C}$ deficiency.

\section{Observations following administration of orange juice to individuals showing a low level of vitamin $C$ saturation}

The question arises whether the administration of vitamin $\mathrm{C}$ in the form of orange juice would suffice to remedy this subclinical degree of deficiency found in such a variety of conditions. In
TABLE III

Influence of vitamin $C$ injection on vitamin $C$ output

\begin{tabular}{|c|c|c|c|c|c|c|}
\hline \multirow{3}{*}{ Name } & \multicolumn{3}{|c|}{$\begin{array}{l}\text { Before course of } \\
\text { orange juice }\end{array}$} & \multicolumn{3}{|c|}{$\begin{array}{l}\text { After course of } \\
\text { orange juice }\end{array}$} \\
\hline & \multirow{2}{*}{$\begin{array}{c}\text { Before } \\
\text { injeo- } \\
\text { tion, } \\
6: 30 \\
\text { to } \\
11 \text { a.m. }\end{array}$} & \multicolumn{2}{|c|}{$\underset{\text { injection }}{\text { After }}$} & \multirow{2}{*}{$\begin{array}{c}\text { Before } \\
\text { injec- } \\
\text { tion, } \\
6: 30 \\
\text { to } \\
11 \text { a.m. }\end{array}$} & \multicolumn{2}{|c|}{$\underset{\text { injection }}{\text { After }}$} \\
\hline & & $\begin{array}{c}11 \\
\text { a.m. } \\
\text { to } \\
1: 30 \\
\text { p.m. }\end{array}$ & $\begin{array}{c}1: 30 \\
\text { to } \\
5: 30 \\
\text { p.m. }\end{array}$ & & $\begin{array}{c}11 \\
\text { a.m. } \\
\text { to } \\
1: 30 \\
\text { p.m. }\end{array}$ & $\begin{array}{c}1: 30 \\
\text { to } \\
5: 30 \\
\text { p.m. }\end{array}$ \\
\hline 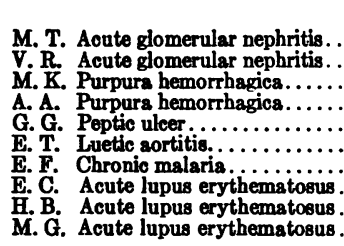 & $\begin{array}{c}\text { mom. } \\
1.5 \\
2.0 \\
1.9 \\
1.7 \\
1.3 \\
1.3 \\
1.2\end{array}$ & \begin{tabular}{|c} 
mom. \\
3.1 \\
3.6 \\
4.2 \\
8.1 \\
2.4 \\
3.0 \\
3.0
\end{tabular} & $\begin{array}{c}\text { mom. } \\
1.1 \\
1.4 \\
3.4 \\
2.4 \\
1.3 \\
1.7 \\
1.3\end{array}$ & $\begin{array}{r}\text { mom. } \\
5.3 \\
5.0 \\
4.9 \\
3.1 \\
6.0 \\
7.0 \\
18.0 \\
2.3 \\
2.4 \\
2.2\end{array}$ & $\begin{array}{r}\text { mom. } \\
20.2 \\
17.6 \\
41.0 \\
19.0 \\
31.6 \\
40.2 \\
75.2 \\
2.9 \\
6.1 \\
6.1\end{array}$ & $\begin{array}{l}\text { mom. } \\
4.8 \\
4.1 \\
5.1 \\
1.8 \\
5.8 \\
6.8 \\
9.8 \\
1.9 \\
2.3 \\
2.0\end{array}$ \\
\hline
\end{tabular}

Table III are shown the results of the administration of from 200 to $400 \mathrm{cc}$. of orange juice daily for 1 week to 7 patients. The saturation test in each of these cases shows practically no rise in excretion of vitamin $\mathrm{C}$ before the patients received orange juice. Following the administration of orange juice for 1 week, the saturation curve in each of the 7 cases becomes normal. This indicates that these subjects became normally saturated with vitamin $\mathrm{C}$.

Similar study of 3 of the cases of acute lupus erythematosus discloses a surprisingly different picture. Table III shows the results of these studies. One patient, M. G., had been receiving a high vitamin $\mathrm{C}$ diet including orange juice and grapefruit for more than two weeks. The saturation test shows practically no rise in excretion following intravenous administration.

Another patient, H. B., received $200 \mathrm{mgm}$. cevitamic acid intravenously every day for 6 days, and was then given about $500 \mathrm{cc}$. of orange juice daily for more than 2 weeks. The vitamin C saturation test showed no rise in excretion, as shown in Table III.

The third case, E. C., had been taking more than ordinarily adequate quantities of orange juice daily for several weeks. Nevertheless, the vitamin $C$ saturation test showed an abnormally low level of excretion.

In the cases of lupus erythematosus, the vitamin C deficiency is apparently not remedied in the same manner as in the other types of cases stud- 
ied-that is, by saturating the patient with orange juice or administering cevitamic acid intravenously.

\section{DISCUSSION}

In an attempt to elucidate the problems of vitamin $\mathrm{C}$ metabolism it has been the object of these studies to answer, if possible, the following questions: 1 . Is there a relatively constant level of urinary excretion of vitamin $\mathrm{C}$ in normal individuals on what is considered a well balanced diet? 2. Is there a change in the excretion level, following the administration of a definite amount of vitamin $\mathrm{C}$ to the normal subject? 3 . Under what conditions is the level of excretion significantly above or below the normal, and what is the response in such conditions to the administration of a similar quantity of vitamin C? 4. Do individuals with hemorrhagic tendencies have characteristically abnormal vitamin $\mathrm{C}$ excretion levels? 5. Are there other pathological conditions which are etiologically in some manner associated with an abnormal vitamin $\mathrm{C}$ excretion level?

From the work of Harris et al. (1) and the corroborating results of this and the previous study (2), it would appear that in normals on the conventional well balanced diet, there is a reasonably constant level of urinary excretion of vita$\min \mathrm{C}$.

The work presented in this paper and also in a previous communication (2) establishes, furthermore, that normally there is a characteristic rise in excretion of vitamin $\mathrm{C}$ in the urine following the intravenous administration of 100 mgm. of vitamin $C$ (cevitamic acid). The excretion level rises within about 2 hours, to about 5 to 6 times the values found before injection. There is a return to the normal level in from 4 to 6 hours following the injection. Because the excretion in these subjects rises to a peak following intravenous injection, with a later fall to preinjection level, it may reasonably be assumed that the vitamin $C$ in their body is at a definite saturation level.

These studies indicate also that there is a very large group in the ward and outpatient department population whose urinary excretion level of vitamin $\mathrm{C}$ is considerably below the normal. It is probable that these patients are representative of their group in the population.
When $100 \mathrm{mgm}$. of cevitamic acid is administered intravenously to any of this group, a rise in excretion fails to occur. This, in the opinion of the writer, is due to the fact that their vitamin $C$ level is considerably below the normal saturation level-that there is a vitamin C deficiency. For that reason the test described here is designated the vitamin $\mathrm{C}$ saturation test. Included in this group are persons with many types of clinical conditions which cannot be associated causally with a vitamin $\mathrm{C}$ deficiency.

Since the isolation of vitamin $\mathrm{C}$, many papers have been written in an effort to prove an etiological relationship between vitamin $\mathrm{C}$ deficiency and hemorrhagic diatheses such as purpura. Many claims of improvement or cure of purpura following treatment with vitamin $C$ have been made on rather questionable evidence. The work presented in this paper indicates that in purpura, as well as in other conditions, there is an abnormally low level of vitamin $C$ in the body and therefore a low level of excretion after intravenous injection of a test dose. This degree of vitamin $\mathrm{C}$ deficiency is, as would appear from this study, not peculiar to purpura. It is questionable, therefore, whether this vitamin $\mathrm{C}$ deficiency is an important etiological factor in the development of purpura-and it is extremely unlikely that it can be the sole etiological factor. This under-saturation with vitamin $\mathrm{C}$ is quickly remedied when orange juice is administered to these persons for a few days. This is shown by the fact that following intravenous injection of the test dose, the urinary excretion curve subsequently becomes normal.

The conclusion seems inescapable that a fairly large proportion of the population, as represented by the groups encountered in the wards and outpatient department of our hospital, suffers from an undersaturation with vitamin $\mathrm{C}$. This might be termed a subclinical vitamin $\mathrm{C}$ deficiency. In most instances this is, undoubtedly, merely part of a general dietary deficiency.

It is not irrelevant, therefore, to sound a warning note to those who in their enthusiasm might misinterpret the significance of this degree of vitamin $\mathrm{C}$ deficiency in patients with purpura and other pathological conditions. Thus far the etiological rôle of vitamin $\mathrm{C}$ deficiency has been dem- 
onstrated in the case of scurvy only. There is not sufficient evidence to indicate that it alone plays a rôle in any other pathological condition characterized by bleeding tendency or by vascular disease.

From the present studies there is a suggestion that the cases of acute lupus erythematosus may be associated with some disturbance in vitamin C metabolism. The 5 cases studied show a persistently low level of vitamin C excretion. Although 3 of these cases received an ordinarily sufficient quantity of orange juice to bring the saturation level to normal, these patients failed to respond in the same manner as did other patients thus treated. When patients with purpura and other conditions received orange juice daily for 1 week, the vitamin $\mathrm{C}$ saturation in the body became normal, as indicated by the test. Of the 3 cases of acute lupus erythematosus, one received large amounts of orange juice daily for several weeks; a second of these received cevitamic acid intravenously for several days, followed by about $500 \mathrm{cc}$. of orange juice daily for some weeks; and the third one had been receiving one or more oranges daily for six weeks. Quantities of vitamin $C$ in excess of the amounts apparently sufficient to overcome vitamin $\mathrm{C}$ deficiency in all other pathological conditions studied did not suffice to accomplish such a result in these 3 cases of acute lupus erythematosus.

The significance, if any, of this failure of the cases of acute lupus erythematosus to respond as do other cases cannot be appraised without further work. The daily administration of orange juice and the daily injection of cevitamic acid was not followed by any improvement in the disease.

\section{SUM MARY}

In the present paper are presented the results of studies of vitamin $C$ saturation and excretion in the urine upon 127 subjects. Besides normal controls, the cases studied included purpura (both thrombocytopenic and symptomatic), acute lupus erythematosus, glomerulonephritis, acute rheumatic fever, rheumatoid arthritis, and jaundice of varied etiology.

1. A test for vitamin $\mathrm{C}$ saturation or subclinical deficiency is presented.

2. In normal individuals the daily ( 24 hour) output of vitamin $\mathrm{C}$ is about 13 to $20 \mathrm{mgm}$.
3. When $100 \mathrm{mgm}$. of vitamin $\mathrm{C}$ is injected intravenously in normal individuals there is a rise in output, within 2 to 3 hours, to an average of about 5 times the pre-injection levels. The peak of post-injection excretion of vitamin $\mathrm{C}$ reaches a level equal to, or considerably above the 13 to 20 mgm. excreted normally in 24 hours, when no cevitamic acid has been administered intravenously.

4. A large percentage of the population encountered in the wards and outpatient department of the Hospital were found to have excretion levels of vitamin $\mathrm{C}$ in the urine considerably below that found in normal subjects living on an adequate mixed diet. When such individuals receive $100 \mathrm{mgm}$. of vitamin $\mathrm{C}$ intravenously, there is practically no rise in urinary excretion of vitamin C. Similarly, degrees of subclinical deficiency could be demonstrated in purpura, and in patients with a variety of other diseases which were corrected by an adequate intake of orange juice for several days.

5. It is therefore maintained that there is, as yet, no evidence to justify a conclusion that vitamin $\mathrm{C}$ deficiency has a causal relationship to any pathological condition other than scurvy. A low excretion level of vitamin $C$ does not warrant the conclusion that vitamin $\mathrm{C}$ deficiency plays an etiological rôle in thrombocytopenic purpura or other conditions which manifest hemorrhagic tendencies.

6. The persistently low excretion level of vita$\min \mathrm{C}$ in acute lupus erythematosus differs from that found in any other condition studied.

\section{BIBLIOGRAPHY}

1. Harris, L. J., Ray, S. N. and Ward, A., The excretion of vitamin $C$ in human urine and its dependence on the dietary intake. Biochem. J., 1933, 27, 2011.

2. Finkle, P., Observations on excretion of vitamin $C$ in some vascular diseases. Proc. Soc. Exper. Biol. and Med., 1935, 32, 1163.

3. Baehr, G., Klemperer, P. and Schifrin, A., A diffuse disease of the peripheral circulation (usually associated with Lupus erythematosus and endocarditis). Tr. A. Am. Physicians, 1935, 50, 139.

4. Rinehart, J. F., Connor, C. L. and Mettier, S. R., Further observations on pathologic similarities between experimental scurvy combined with infection, and rheumatic fever. J. Exper. Med., 1934, $59,97$.

5. Szent-Györgyi, A., Die medizinische und biologische Bedeutung des Vitamin C. Verhandl. d. Gesellsch. f. Verdauungs. u. Stoffwechselkr., 1934, 12, 49. 